\title{
Challenges and Opportunities Faced on Food Production Systems in Arid and Semi-Arid Regions under Climate Change Conditions
}

\author{
J ahan $\mathrm{M}^{*}$ and Ghalenoei Sh \\ Department of Agrotechnology, Faculty of Agriculture, \\ Ferdowsi University of Mashhad (FUM), Iran \\ *Corresponding author: Mohsen J ahan, Department \\ of Agrotechnology, Faculty of Agriculture, Ferdowsi \\ University of Mashhad (FUM), Iran; Email: jahan@ \\ ferdowsi.um.ac.ir; ORCiD: 0000-0003-2259-5124
}

Received: December 23, 2021; Accepted: February 02, 2022; Published: February 09, 2022

\begin{abstract}
Climate change and variability may have an impact on the occurrence of food safety hazards at various stages of the food chain. It may also affect socio-economic aspects related to food systems such as agriculture, animal production, global trade, demographics and human behavior which all influence food safety. There is also concern that meeting the rising demand for food is leading to environmental degradation thereby exacerbating factors in part responsible for climate change, and further undermining the food systems upon which food security is based. A major emphasis of climate change/food security research over recent years has addressed the agronomic aspects of climate change, and particularly crop yield. Therefore, while agronomic research alone cannot address all food security/climate change issues, hence the balance of investment in research and development for crop production vis a vis other aspects of food security needs to be assessed. Improved understanding of the impacts of climate change on crop production helps to develop adaptation options, and also crucially it improves understanding of the consequences of different adaptation options on further climate forcing. This role can further be strengthened if agronomists work alongside other scientists to develop adaptation options that are not only effective in terms of crop production, but are also environmentally and economically robust, at landscape and regional scales. Furthermore, such integrated approaches are much more likely to address the information need of policy makers. The potential for stronger linkages between the results of agronomic research and the policy environment will thus be enhanced.
\end{abstract}

Keywords: Food systems; Environmental variability; Adaptation strategies

\section{Introduction}

\section{Food security}

Maintaining food security depends on finding suitable solutions to adapt crop production systems and manage its consequences at the regional and local scales. As a strategy to protect and improve the poor liveliness and guarantee food security, the top concern for agricultural development is to reduce the vulnerability of agricultural systems to climate change [1,2].

Debate about global water scarcity and food security has intensified in recent times, and precise estimates of future water and food demand are elusive. Climate change is adding another layer of complexity. The global human population may hit a record 12 billion people by 2050. The much-needed increase in food production is not forthcoming. The bulk of the increase in food production must come from areas currently cultivated through increase in water and energy use efficiency. There are many factors that affect food safety such as global trade, socio-economic and technological development, urbanization and agricultural land use. Temperature increases (Figure 1) and changes in rainfall patterns have an impact on the persistence and patterns of occurrence of bacteria, viruses, parasites and fungi and the patterns of their corresponding foodborne diseases. Such changes also have an impact on microbial ecology and growth, plant and animal physiology and host susceptibility which may result in the emergence, redistribution and changes in the incidence and intensity of plant and animal diseases and pest infestations, all of which could impact foodborne diseases and zoonosis [3].

Extreme weather events such as floods and droughts may lead to contamination of soil, agricultural lands, water and food and animal feed with pathogens, chemicals and other hazardous substances, originating from sewage, agriculture and industrial settings. Emergency situations after natural disasters are of special concern for water and food sanitation. Ocean warming, and climate change related acidification and changes in ocean salinity and precipitation also affect the biochemical properties of water, along with water micro flora, fisheries distribution, fish metabolic rates, and persistence and patterns of occurrence of pathogenic vibrios, harmful algal blooms and chemical contaminants in fish and shellfish.

\section{Anthropogenic effects on climate change}

Human activities related to the production, supply and consumption of food, are partly responsible for changing the world's climate and giving rise to other, and globally and locally important environmental changes. Such environmental changes include those 
in freshwater supplies, carbon and nitrogen cycling, biodiversity, and land cover and soils. While climate change may bring benefits to some parts of the world, especially northern latitudes above about 558, there is growing concern that overall, these changes, and especially those associated with climate, will further complicate achieving food security for those in the developing world. This is due to the generally predicted deleterious impacts on agriculture, in particular in tropical and sub-tropical countries $[4,5]$. There are three main reasons: first, many parts of the developing world are anticipated to be exposed to significant changes in temperature and rainfall patterns. Climate assessments for Southern Africa, for instance, conclude that the region will become warmer and drier [6]; a temperature increase of $2-58 \mathrm{C}$ is predicted over coming decades [7] and increasingly variable rainfall is anticipated, with the region becoming generally drier, especially in the east. An increase in both frequency and intensity of extreme events (droughts and floods) is also anticipated $[7,8]$ Second, developing economies are particularly sensitive to the direct impacts of climate change given their often-heavy dependence on agriculture and ecosystems, and because of their high poverty levels and geographic exposure. Third, many people in the developing world depend directly on agriculture as their primary source of food, and negative impacts on crop productivity will affect crop production and thereby overall food supply at the local level.

\section{Agronomic research on the impacts of climate change: Challenges and opportunities}

In preparation for the High-Level Conference on World Food Security: The Challenges of Climate Change and Bioenergy in 2008, the Food and Agriculture Organization of the United Nations (FAO) organized several expert consultations on the impacts of climate change on diverse issues related to food security, including the impacts on animal and plant health, implications for emergencies, etc. FAO also commissioned the production of background documents on the impacts of climate change on food and nutrition security, food safety and other relevant subjects. Among many sources of information, this paper reviews the background documentation on the impacts of climate change on food safety; the outcomes of the FAO expert consultations on climate change, trans-boundary diseases and pests; and the consultation on climate change and emergencies that were prepared for the FAO High-Level Conference on the Challenges of
Climate Change in 2008. The definitions of the terms related to food safety and the framework used to analyze the impacts of climate change on food safety correspond to the FAO description of a food control system [9]. Definitions of the terms related to climate such as climate change and variability, vulnerability and adaptation correspond to those included in the Glossary of the Intergovernmental Panel for Climate Change [10].

Advances in crop breeding and agronomy have enabled increase in crop yields over the last 40 years or so. In Europe, for instance, yields have increased steadily and approximately linearly over the last 45 years (Figure 2), and in the USA, similarly, linear increases in maize, rice and wheat yields (61, 54 and $41 \mathrm{~kg} \mathrm{ha}^{-1}$ year $^{-1}$, respectively) have been recorded over the last 50 years (K. Cassman, personal communication).

These advances have resulted from a fortuitous combination of factors including scientific advances in irrigation practices, fertilizer formulation and application technologies, weed control including herbicides, disease and pathogen control using pesticides, and improvements in crop phenotype from breeding especially the widespread adoption of semi-dwarfing genes in cereals [11]. Until recently most assessments of the impacts of climate change have been made assuming no modification to crop production practices. It is highly probable, though, that the changes of climate and $\left(\mathrm{CO}_{2}\right)$ will occur sufficiently slowly that changes to sowing date, cultivar, crop and other management practices will allow at least some adaptation of the production system by farmers. Several adaptations are conceivable in the timescale available including [23]:

- Crop selection to determine mechanisms and sources of durable disease resistance.

- Crop selection to identify mechanisms and sources of resistance/resilience to abiotic stresses including heat, cold and drought.

- $\quad$ Genetic enhancement to cope with more variable growing conditions.

- Development of new crops to take advantage of more favorable growing conditions.

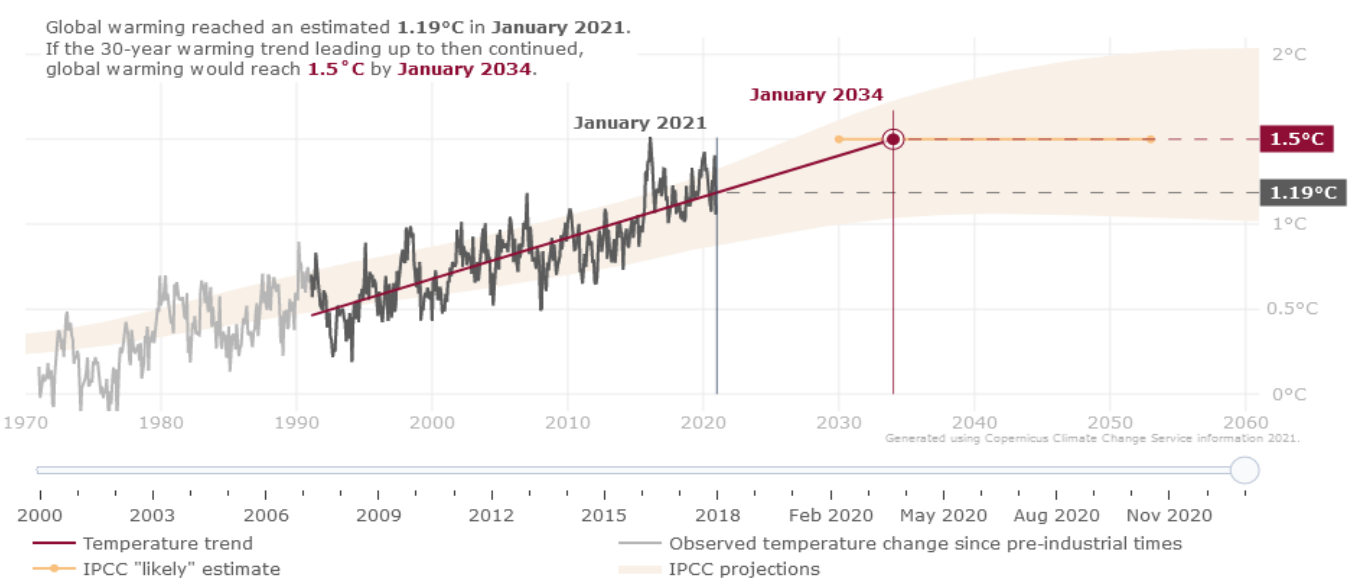

Figure 1: Observed and estimated global temperature trend during 2000 to 2060. (Source: Global temperature trend monitor: https://cds.climate.copernicus.eu). 


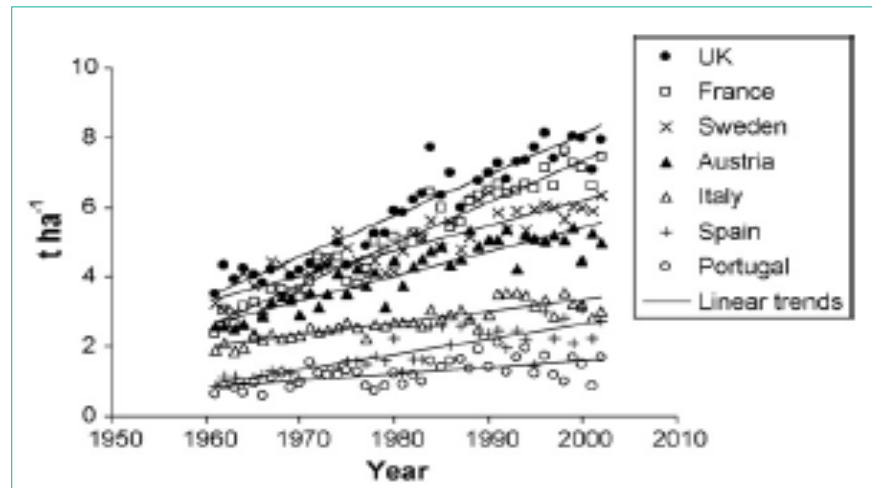

Figure 2: Observed wheat grain yields for selected countries in Europe (curtsy of Ewert et al.).

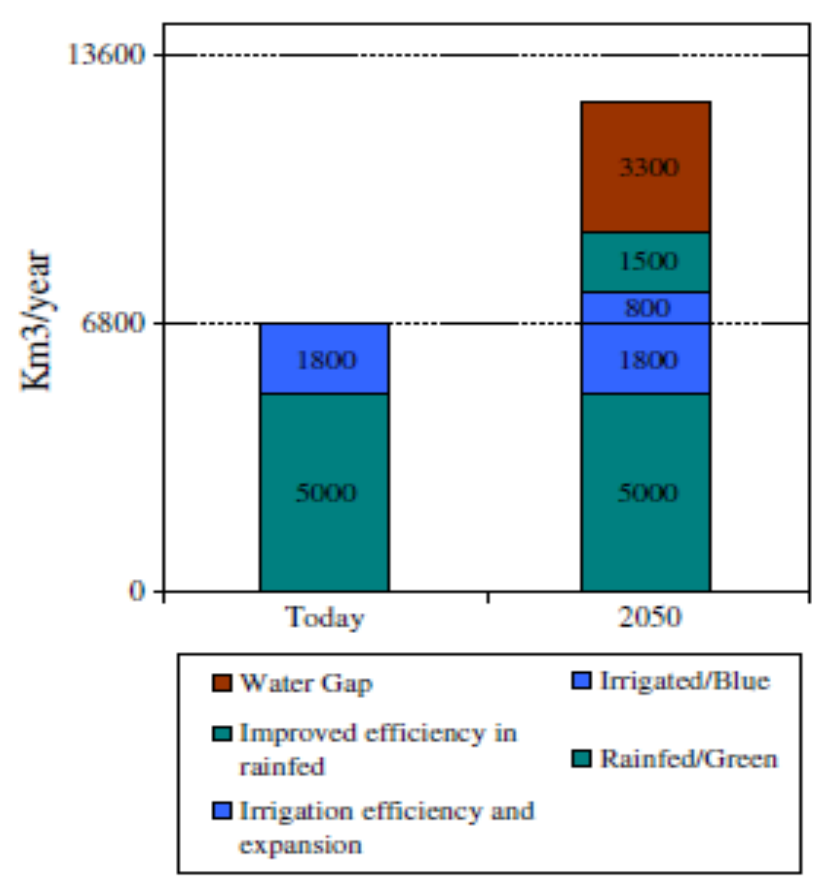

Figure 3: World water demand to 2050 food security [17].

- Movement of some cropping systems from locations where climate has become unsuitable to locations that have become more favorable.

To harness climate posed difficulties, several potential adaptation alternatives have been recommended for developing countries. For instance, soil and water conservation practices have been suggested in reaction to soil erosion crisis caused by climate [13]. Intensification will contribute to increases in production (total amount produced) but increases via this method are limited by the availability of new land, and the tradeoffs with greenhouse gas emissions and other deleterious environmental impacts [14]. About 3 billion ha of the world's land is suitable for arable agriculture and 1.2-1.5 billion ha of the most productive land is already cultivated [15]. Most of the potentially available land is presently under tropical forests so cultivation of more of this land is undesirable with respect to biodiversity conservation, greenhouse gas emissions and regional climate and hydrological changes. Cultivation for agriculture would also incur high costs to provide the necessary infrastructure. In general, then, further intensification of agriculture will likely provide only a small fraction of the increased production needed. Typically, new areas of crop land will only contribute $7.4 \%$ (51 Mha) to cereal production on a global basis by 2020 with estimated contributions of intensification to crop production range from $47 \%$ in sub-Saharan Africa to $18 \%$ in South Asia [16]. It will be up to the governments of the countries concerned to decide whether tropical forest conversion is a policy option for their country.

Population and income growth will increase the demand for food and water. Irrigation will be the first sector to lose water as water competition by non-agricultural uses increases and water scarcity intensifies. Increasing water scarcity will have implications for food security, hunger, poverty, and ecosystem health and services. Feeding the 2050 population will require some $12,400 \mathrm{~km}^{3}$ of water, up from $6800 \mathrm{~km}^{3}$ used today (Figure 3). This will leave a water gap of about $3300 \mathrm{~km}^{3}$ even after improving efficiency in irrigated agriculture, improving water management, and upgrading of rain fed agriculture [17]. This gap will lead to a food gap unless concerted actions are taken today. Disrupted access to energy can further deepen the food production gap. The currently unknown adaptation deficit in water management as a response to climate change poses further challenges to future food security.

Agronomists also need to work with a wide range of other disciplines, and across sectors of the food industry, to develop the necessary new research approaches and paradigms to better link research on food production to food security issues. Such novel approaches more likely to deliver scientific outputs better suited to the information needs of policy makers.

\section{Climate change and food safety impacts}

Climate related changes may impact all three elements of the epidemiologic triad (host, agent, and environment). Climatic factors can affect (1) the sources and modes of transmission and (2) the growth and survival of pathogens in the environment and the microbial ecology and (3) the food matrix, among others [3]. The complexity of the ways of transmission illustrates the susceptibility of these environments to be affected by climatic factors, in particular extreme weather events involving flooding. Diarrhoeal disease is one of the most important causes of ill-health in the world and is climate sensitive, showing strong seasonal variations [18]. Higher temperature has been found to be strongly associated with increased episodes of diarrhoeal disease in adults and children in Peru, where diarrhoeal reports increased $8 \%$ for each degree of temperature increase [19]. Associations between climate-related extreme weather events and monthly reports of outbreaks of infectious water-borne disease also have been reported worldwide.

Farmers never had a chance to make a surplus - and then invest - as governments could not resist the opportunity to import cheap food. A fundamental shift is needed in water and energy use in food systems policy to avoid a severe food crisis in the future. Enhancing food security requires governments and donors to deal forcefully with the underlying issues driving food security, such as population growth, widespread poverty and income inequality, climate change, water scarcity, land degradation, energy and food price inflation. This 
requires investments for: tackling climate change; conserving water and energy resources; developing, adopting and adapting climate resilient varieties; modernizing irrigation; shoring up domestic food supplies; reengaging in agriculture for further development; and reforming global food market and trade.

The issues and approaches may be well accepted but investing in the global commons is the greatest challenge faced by the global community. Unprecedented global cooperation is required to address the institutional, governance and financial constraints to ensure future food security for all by 2050 and beyond. While agronomic research alone cannot solve all food security/climate change issues (and hence the balance of investment in research and development for crop production vis a vis other aspects of food security needs to be assessed), it will nevertheless continue to have an important role to play: it both improves understanding of the impacts of climate change on crop production and helps to develop adaptation options; and also - and crucially - it improves understanding of the consequences of different adaptation options on further climate forcing. This role can further be strengthened if agronomists work alongside other agricultural scientists to develop adaptation options that are not only effective in terms of crop production, but are also environmentally and economically robust, at landscape and regional scales.

Climate change impacts on animal health and veterinary public health: potential pathways

Pathways through which climate change may impact animal health and veterinary public health issues include:

- Increase in the susceptibility of animals to disease.

- Increase in the range or abundance of vectors/animal reservoirs and prolonging the transmission cycles of vectors.

- Impact of climate change on farming/husbandry practices (including the use of veterinary drugs).

The risk of emerging zoonosis may increase due to climate related changes in the survival of pathogens in the environment, changes in migration pathways, carriers and vectors and changes in the natural ecosystems. Zoonosis such as Rift Valley fever, West Nile Fever, tickborne diseases and non-zoonotic animal diseases such as blue tongue, African Horse Sickness, African swine fever are examples of animal diseases whose distribution will be strongly influenced by climate change and variability $[20,21]$.

Climate change affects animals' living conditions which are conducive to pathologies such as parasitic diseases (e.g., infestation/ affection by nematodes and taenia), nutritional disorders, sunstroke or dehydration [21]. Exposure to intense cold, droughts, excessive humidity or heat may predispose cattle to complex bacterial syndromes such as mastitis which may require the use of antibiotics. Aquatic animals particularly vulnerable to climate change because their related metabolic processes are influenced by water temperature, salinity, and oxygen levels and their ecosystems are fragile. Fish, including shellfish, respond directly to climate fluctuations as well as to changes in their biological environment (predators, species interactions, disease). In the aquaculture sector, problems expected from a warming environment include a greater susceptibility of disease, particularly in intensive systems [22].
The proliferation of animal diseases due to climate related changes may result in an increased use of veterinary drugs that could lead to increased and possibly unacceptable levels of veterinary drugs in foods of animal origin [3]. This may have public health and trade consequences.

\section{Conclusion}

Investments are needed today for enhancing future food security; this requires action on several fronts, including tackling climate change, preserving land and conserving water, reducing the energy footprint in food systems, developing and adopting climate resilient varieties, modernizing irrigation infrastructure, shoring up domestic food supplies, reforming international food trade, and responding to other global challenges.

Climate change and variability may affect other underlying drivers of food safety such as agriculture, crop production and plant health, animal production and animal health, fisheries, aquaculture, food trade, food and feed manufacturing, processing and handling and consumer's behavior. These impacts in turn have substantial public health, economic, social and environmental consequences. A better understanding of all the changes that might arise in view of climate change and variability is an essential first step to ensuring preparedness for emerging food risks. Food consumption and its immense role in the demand for and types of food and volumes of water, and unfair trade relations must be recognized as challenges to food security. The developing economies and especially those located in arid and semi-arid regions have dismal crop yields for many reasons but one of the most important is global food prices over the past half century.

\section{References}

1. Bradshaw B, Dolan A and Smit B. Farm-level adaptation to climatic variability and change: crop diversification in the Canadian prairies. Climatic Change. 2004; 67: 119-141.

2. Wang J, Mendelsohn R, Dinar A, Huang J. How do China's farmers adapt to climate change? Paper presented at the International Association of Agricultural Economics Conference, Beijing. 2009.

3. FAO. Food Outlook: Global Market Analysis. FAO, Rome. 2008.

4. Fischer G, Shah M, van Velthuizen H, Nachtergaele FO. Global Agroecological Assessment for Agriculture in the $21^{\text {st }}$ Century. International Institute for Applied Systems Analysis, Laxenburg, Austria. 2001.

5. Hadley-Centre. Effects of Climate Change in the Developing Countries. UK Met Office. 2006.

6. Hulme M, Doherty R, Ngara T, New M, Lister D. Africa climate change 19002100. Climate Res. 2001; 17: 145-168.

7. IPCC. Africa. In: McCarthy JJ, Canziani O, Leary NA, Dokken DJ, White KS. (Eds.), Climate Change 2001: Impacts, Adaptation and Vulnerability. Contribution of Working Group II to the Third Assessment Report of the Intergovernmental Panel on Climate Change. Cambridge University Press, Cambridge. 2001.

8. Tyson P, Odada E, Schulze R, Vogel Cl. Regional-global change linkages: Southern Africa. In: Tyson P, Fuchs R, Fu C, Lebel L, Mitra AP, Odada E, et al. (Eds.), Global-regional Linkages in the Earth System. START/IHDP/IGBP/ WCRP. Springer, Berlin, London. 2002.

9. FAO. World Agriculture: Towards 2015/2030. An FAO Perspective. Food and Agriculture Organization of the United Nations/Earthscan, Rome, Italy/USA. 2003.

10. Baede AMP. Climate change: The physical science basis. Contribution of 
working group I to the fourth assessment report of the intergovernmental panel for climate change (Glossary, Appendix I). Cambridge and New York: Cambridge University Press. 2007.

11. Evans LT. Feeding the Ten Billion. Cambridge University Press Cambridge Ewert F, Rounsevell MDA, Reginster I, Metzger MG, Leemans R. Future scenarios of European agricultural land use. I. Estimating changes in crop productivity. Agric. Ecosyst. Environ. 1998; 107: 101-116.

12. Jahan M, Nassiri Mahallati M. Modeling the response of sesame (Sesamum indicum L.) growth and development to climate change under deficit irrigation in a semi-arid region. 2021.

13. McCarthy N, Lipper L, Branca G. Climate-Smart Agriculture: Smallholder Adoption and Implications for Climate Change Adaptation and Mitigation. Mitigating Climate Change in Agriculture Series. 2011; 4: 1-37.

14. Gregory PJ, Ingram JSI, Andersson R, Betts RA, Vrovkin V, Chase TN, et al. Environmental consequences of alternative practices for intensifying crop production. Agric. Ecosyst. Environ. 2002; 88: 279-290.

15. Greenland DG, Gregory PJ, Nye PH. Land resources and constraints to crop production. In: Waterlow JC, Armstrong DG, Fowden L, Riley R. (Eds.) Feeding a World Population of More than Eight Billion People: A Challenge to science. Oxford University Press, Oxford. 1998: 39-55.

16. Alexandratos N. World Agriculture: Towards 2010: a FAO Study. Wiley, Chichester. 1995.

17. de Fraiture C, Wichelns D, Rockström J, Kemp-Benedict E, Eriyagama N Gordon LJ, et al. Looking ahead to 2050: scenarios of alternative investment approaches. In: Molden D. (Ed.), Comprehensive Assessment of Water Management in Agriculture, Water for Food, Water for Life: A Comprehensive Assessment of Water Management in Agriculture. International Water Management Institute, London: Earthscan, Colombo. 2007: 91-145.
18. Kovats S, Tirado C. Climate, weather and enteric disease. In B Menne \& KL Ebi (Eds.), Climate change and adaptation: Strategies for human health. 2006: 269-290. Darmstadt: WHO, Steinkopff Verlag.

19. Checkley W, Epstein LD, Gilman RH, Figueroa D, Cama RI, Patz JA, et al. Effects of El Nino and ambient temperature on hospital admissions for diarrhoeal diseases in Peruvian children. Lancet. 2000; 355: 442-450.

20. Easterling WE, Aggarwal PK, Batima P, Brander KM, Erda L, Howden SM, et al. Food, fiber, and forest products. In ML Parry, OF Canziani, JP Palutikof, PJ van der Linden, \& CE Hanson (Eds.), Climate change 2007: Impacts, adaptation, and vulnerability. Contribution of working group II to the fourth assessment report of the intergovernmental panel on climate change. Cambridge, UK: Cambridge University Press. 2007.

21. EC. Adapting to climate change: Towards a European framework for action human, animal and plant health impacts of climate change. Commission staff working document. Accompanying document to the white paper (COM (2009) 147 final). 2009.

22. Shriner DS, Street RB. North America. Climate change 2007: Impacts, adaptation and vulnerability. In ML Parry, OF Canziani, JP Palutikof, PJ van der Linden, \& CE Hanson (Eds.), Contribution of working group II to the fourth assessment report of the intergovernmental panel on climate change. Cambridge, UK: Cambridge University Press. 2007.

23. Amiri MB, Jahan M Moghaddam PR. An exploratory method to determine the plant characteristics affecting the final yield of Echium amoenum Fisch. \& CA Mey under fertilizers application and plant densities. Sci. Rep. 2022; 12: 1881. 